\title{
sciendo
}

\section{Editorial for the Special Issue: "Contemporary Issues in Statistical Methods and Data Science Applications" in Croatian Review of Economic, Business and Social Statistics}

\author{
Berislav Žmuk \\ University of Zagreb Faculty of Economics and Business, Department of \\ Statistics, Zagreb, Croatia \\ bzmuk@efzg.hr \\ Anita Čeh Časni \\ University of Zagreb Faculty of Economics and Business, Department of \\ Statistics, Zagreb, Croatia \\ aceh@efzg.hr
}

DOI: $10.2478 /$ crebss-2020-0006

The special issue of Croatian Review of Economic, Business and Social Statistics (CREBSS) is focusing on contemporary issues in statistical methods and data science applications. CREBSS is the first statistical journal established in Croatia and it is published by Croatian Statistical Association (CSA).

Statistical methods have widespread use in different application areas. Statistical methods have shown to be very useful methods which, for example, can improve production processes, help in decision making, forecasting and simulate developments in the future periods. However, depending on the analysed processes, available data and used statistical methods, different issues can appear in practice.

This special issue brings six papers that cover using statistical methods and their ability of issues solving in different areas like stock market prediction and stock selection, COVID-19 spread analysis, presentation skills of business and economics students, measurement errors of different survey modes and tourism traffic administrative evidence.

In the field of stock market analysis, Vlah Jerić (2020) compares different classification algorithms for prediction on CROBEX data. The author tested overall five different classification algorithms and evaluated their performance.

On the other hand, Vuković, Pivac and Babić (2020) inspected possibilities of selecting an optimal set of investment stocks. In order to select the best stock for investment the authors applied different hybrid multiple criteria decision-making approaches.

Jošić (2020) tackles the issue of different COVID-19 spread rates in 111 countries worldwide. In order to investigate that issue the author included variety of socioeconomics variables in estimated statistical models. 
Ćurlin, Pejić Bach and Miloloža (2020) are emphasizing the importance of presentation skills of business and economics students. In order to detect common characteristics of different group of students, the authors applied non-hierarchical kmeans analysis.

Centrih, Viršček, Smukavec, Bučar and Arnež (2020) inspected the sources of mode measurement errors based on data from the survey of daily passenger mobility of Slovenian residents conducted in 2017. The results from this mixed mode survey enabled the use of the regression modelling for two key statistic estimates: the number of trips in a day and the daily distance.

The problems and challenges of administrative data sources in measuring noncommercial tourism traffic are emphasized by Marušić, Kožul and Brozović (2020). The authors came to the conclusion that existing secondary and administrative data sources are not enough to improve the estimates in the eVisitor system in Croatia.

Finally, the contemporary issues that research papers in this special issue are dealing with, are just examples of questions that appear in practice where statistical methods and data science can be applied. No matter that the research papers are suggesting solutions for only small amount of issues in the specific areas, these few examples are showing that we can make better world by using appropriate statistical methods.

\section{References}

1. Vlah Jerić, S. (2020). Comparing classification algorithms for prediction on CROBEX data. Croatian Review of Economics, Business and Social Statistics, Vol. 6, No. 2, pp. 4-11.

2. Jošić, H. (2020). The socio-economic catalysers of COVID-19 pandemic. Croatian Review of Economics, Business and Social Statistics, Vol. 6, No. 2, pp. 12-26.

3. Ćurlin, T., Pejić Bach, M., Miloloža, I. (2020). Presentation skills of business and economics students: Cluster analysis. Croatian Review of Economics, Business and Social Statistics, Vol. 6, No. 2, pp. 27-42.

4. Centrih, V., Viršček, A., Smukavec, A., Bučar, N., Arnež, M. (2020). Presentation skills of business and economics students: Cluster analysis. Croatian Review of Economics, Business and Social Statistics, Vol. 6, No. 2, pp. 43-57.

5. Vuković, M., Pivac, S., Babić, Z. (2020). Comparative analysis of stock selection using a hybrid MCDM approach and modern portfolio theory. Croatian Review of Economics, Business and Social Statistics, Vol. 6, No. 2, pp. 58-68.

6. Marušić, Z., Kožul, M., Brozović, I. (2020). Measuring non-commercial tourism traffic in Croatia: Challenges of using administrative data. Croatian Review of Economics, Business and Social Statistics, Vol. 6, No. 2, pp. 69-81.

\section{Guest Editors of the CREBSS Special Issue:}

Berislav Žmuk

Anita Čeh Časni

Zagreb, December 2020 


\section{About the Editors of the Special Issue}

Berislav Žmuk graduated at the major Accounting, post-graduated Statistical Methods for Economic Analysis and Forecasting, and gained his PhD degree in Business Economics at Faculty of Economics and Business, University of Zagreb. Currently he is an Assistant Professor at Department of Statistics, Faculty of Economics and Business, University of Zagreb where he teaches the following courses: Statistics, Business Statistics and Business Forecasting. In 2013, he successfully completed Sampling Program for Survey Statisticians (SPSS) at Survey Research Center (SRC), Institute for Social Research (ISR), and University of Michigan in Ann Arbor, Michigan, USA. In 2015 and 2018, he completed several survey methodology courses (Introduction to Web Surveys, Introduction to Questionnaire Design, Mixed-Mode and Mixed Device Surveys, Applied Multiple Imputation, Web Survey Design, Sampling, Weighting, and Estimation) at Gesis, Leibniz Institute for Social Research in Cologne, Germany. In 2016, he completed another two survey methodology courses (Introduction to Survey Data Analysis, Advanced Survey Data Analysis and Survey Experiments) at Essex Summer School in Social Science Data Analysis in Colchester, United Kingdom. His main research fields include applications of statistics in business and economy, survey methodology and statistical quality control. The guest editor can be contacted at bzmuk@efzg.hr.

Anita Čeh Časni is an Assistant Professor at Department of Statistics, Faculty of Economics and Business, University of Zagreb. She received her PhD in Quantitative Economics in 2013. She teaches Statistics and Business statistics both in Croatian and English study programme. Apart from teaching, she is very active in her scientific field having taken part in several domestic and international scientific projects and published more than 60 research papers in international scientific journals. She is also a reviewer for several international journals. Her fields of interest are statistics, econometric modelling of macroeconomic data, panel data linear analysis and housing wealth. The guest editor can be contacted at aceh@efzg.hr. 